\title{
Preparation of a Cell-free Ethylene-forming System from Penicillium digitatum
}

\author{
Hideo Fukuda, Takao FuJII and Takahira Ogawa \\ Department of Applied Microbial Technology, \\ The Kumamoto Institute of Technology, \\ 4-22-1, Ikeda, Kumamoto 860, Japan
}

Received October 7, 1985

\begin{abstract}
An ethylene-forming enzyme was partially purified from Penicillium digitatum IFO 9372 by means of DEAE-Sepharose CL-6B ion exchange chromatography, and a cell-free ethylene-forming system was constructed. Using this system as a tool for elucidation of the biochemical basis of the ethylene formation, the immediate precursor of ethylene was found to be $\alpha$-ketoglutarate and essential factors were L-arginine and the ferrous ion under reduced conditions. It was strongly suggested that this cell-free ethylene-forming system operates in living cells of $P$. digitatum on comparison of the time course of ethylene-forming activity of the cell-free system with that of living cells.
\end{abstract}

Many studies have been performed on ethylene-forming mechanisms in plants and microorganisms. ${ }^{11}$ The production of ethylene by microorganisms has been studied mostly in Penicillium digitatum Sacc., the green mold of citrus fruit, which produces large quantities of ethylene. The immediate precursor of ethylene was confirmed to be L-methionine in plants, ${ }^{1,2)}$ but not for microorganisms. ${ }^{3,4)}$ Some workers obtained evidence of ethylene formation through the Krebs cycle pathway in the fungus. ${ }^{5 \sim 7)}$ Chou and Yang ${ }^{8)}$ demonstrated that the carbon unit of ethylene originated from carbons 3 and 4 of glutamate or those of $\alpha$ ketoglutarate in ${ }^{14} \mathrm{C}$-labeled experiments. Despite the numerous attempts to prepare cellfree ethylene-forming systems from many plant tissues and microbial cells, the construction of one was not achieved. In this paper, we describe the partial purification of an ethylene-forming enzyme, and the construction of a cell-free ethylene-forming reaction system, from Penicillium digitatum IFO 9372.

\section{MATERIALS AND METHODS}

Microorganism and culture conditions. Penicillium digi- tatum Saccardo IFO 9372 was inoculated into a $500 \mathrm{ml}-$ Erlenmeyer flask containing $100 \mathrm{ml}$ of a medium composed of $4 \%$ glucose, $0.5 \%$ peptone, $0.2 \%$ yeast extract, $0.3 \%$ meat extract, $0.001 \% \mathrm{FeSO}_{4} \cdot 7 \mathrm{H}_{2} \mathrm{O}, 0.2 \% \mathrm{NaCl}$ and $3 \%$ sodium carboxymethyl cellulose (Na-CMC) (w/v, pH 6.0), followed by incubation at $25^{\circ} \mathrm{C}$ for 4 days on a rotary shaker at $180 \mathrm{rpm}, 70 \mathrm{~mm}$ amplitude. To prevent pellet formation during fungal cultivation, the seed culture was supplemented with $\mathrm{Na}-\mathrm{CMC}$. The culture was trasferred to the above medium (without $\mathrm{Na}-\mathrm{CMC}$ ), at the inoculum size of $5 \%(\mathrm{v} / \mathrm{v})$, and cultivated at $25^{\circ} \mathrm{C}$ for 4 days on the rotary shaker.

Preparation of a cell-free extract. Cells were harvested from the culture broth by filtration, washed with $2 \mathrm{~mm}$ HEPES $\left(N\right.$-2-hydroxyethylpiperazine- $N^{\prime}-2$-ethanesulfonic acid) buffer solution ( $\mathrm{pH} 7.0)$ and then ground at $4^{\circ} \mathrm{C}$ for $20 \mathrm{~min}$ with an aliquot of sea sand. A cellfree extract was obtained from the cell homogenate by centrifugation $(9,000 \times g)$ at $4^{\circ} \mathrm{C}$ for $20 \mathrm{~min}$.

Crude enzyme preparation. Ammonium sulfate was added to the cell-free extract. The precipitates that salted out at 40 to $60 \%$ saturation were harvested by centrifugation at $10,000 \times g$ at $4^{\circ} \mathrm{C}$ for $20 \mathrm{~min}$ and then dissolved in $10 \mathrm{~mm}$ HEPES buffer ( $\mathrm{pH} 8.0$ ). After dialysis against the same buffer solution for $c a .12 \mathrm{hr}$, the undissolved materials were removed by centrifugation and the clear supernatant solution was used as the crude enzyme preparation.

DEAE-Sepharose chromatography. The crude enzyme preparation was applied onto a $4 \times 15 \mathrm{~cm}$ column of DEAE-Sepharose CL-6B (Pharmacia P-L Biochemicals, 
Japan) equilibrated with $10 \mathrm{~mm}$ HEPES buffer ( $\mathrm{pH} 8.0$ ). Linear gradient elution was carried out with sodium chloride, from 0 to $0.3 \mathrm{M}$, in the buffer solution. Fractions (each $20 \mathrm{ml}$ ) from the column were collected and stored in a refrigerator at $-80^{\circ} \mathrm{C}$ until measurement of ethylene-forming activity.

Assay of ethylene. A test tube (15-mm diameter, 13-ml capacity) containing a reaction mixture was sealed with a rubber stopper and then incubated on a reciprocal shaker at $25^{\circ} \mathrm{C}$ for $10 \mathrm{~min}$. In the case of ethylene production with living cells, culture broth $(1 \mathrm{ml})$ was transferred to a sterile test tube (18-mm diameter, 34-ml capacity). The test tube was sealed with a rubber stopper and then incubated on a reciprocal shaker at $25^{\circ} \mathrm{C}$ for 1 to $2 \mathrm{hr}$. After incubation, a gas sample $(1 \mathrm{ml})$ was withdrawn through the stopper with a gas syringe and ethylene was determined with a Yanako gas chromatograph G 3800 under the following conditions: column size, $3 \mathrm{~mm} \times 4 \mathrm{~m}$; solid phase, active alumina; temperature, $150^{\circ} \mathrm{C}$; carrier gas, nitrogen at a flow rate of $50 \mathrm{ml} / \mathrm{min}$; and detector, FID. The rate of ethylene formation was calculated as previously re.ported. ${ }^{9)}$

Measurement of cell concentration. The cell concentration was determined from the dry cell weight after drying at $90^{\circ} \mathrm{C}$ overnight.

Measurement of glucose concentration. The glucose concentration in a supernatant was measured by the Glucostat (Worthington Biochemical Co., Freehold, NJ) method.

Measurement of protein concentration. The protein concentration was measured as the optical density at $280 \mathrm{~nm}$, which was converted to the protein concentration with bovine serum albumin as standard.

Chemicals. L-[U- $\left.-{ }^{14} \mathrm{C}\right]$ Arginine and $\left[\mathrm{U}^{-14} \mathrm{C}\right] \alpha$-ketoglutaric acid were purchased from NEW Research Products (Boston). Other chemicals were of analytical grade and from Wako Pure Chemical Ind. (Osaka), unless otherwise noted.

\section{RESULTS AND DISCUSSION}

Factors necessary for ethylene formation by the cell-free extract or crude enzyme preparation In order to construct a cell-free ethyleneforming system, we first determined the substrates needed for the ethylene formation among some probable compounds. The reaction mixture and incubation conditions were as follows: $0.1 \mathrm{ml} 10 \mathrm{~mm}$ substrate, $0.1 \mathrm{ml}$ $20 \mathrm{~mm}$ dithiothreitol, $0.5 \mathrm{ml} 50 \mathrm{~mm}$ HEPES buffer ( $\mathrm{pH} 8.0$ ), $0.1 \mathrm{ml} \mathrm{H}_{2} \mathrm{O}$ and $0.2 \mathrm{ml}$ cell-free
Table I. Effects of Metals on Ethylene Formation

The crude enzyme solution was used.

\begin{tabular}{lc}
\hline \multicolumn{1}{c}{$\mathrm{Metal}^{a}$} & $\begin{array}{c}\text { Ethylene production rate } \\
(\mathrm{nl} / \mathrm{mg} \text { protein } / \mathrm{hr})\end{array}$ \\
\hline $\mathrm{FeSO}_{4} \cdot 7 \mathrm{H}_{2} \mathrm{O}$ & 5.21 \\
$\mathrm{Al}_{2}\left(\mathrm{SO}_{4}\right)_{3}$ & 0.51 \\
$\mathrm{Fe}_{2}\left(\mathrm{SO}_{4}\right)_{3} \cdot x \mathrm{H}_{2} \mathrm{O}$ & 0.50 \\
$\mathrm{~K}_{2} \mathrm{SO}_{4}$ & 0.29 \\
$\mathrm{~K}_{2} \mathrm{~B}_{4} \mathrm{O}_{7} \cdot x \mathrm{H}_{2} \mathrm{O}$ & 0.26 \\
$\left(\mathrm{NH}_{4}\right)_{6} \mathrm{Mo}_{7} \mathrm{O}_{24} \cdot 4 \mathrm{H}_{2} \mathrm{O}$ & 0.24 \\
$\mathrm{CaCl}_{2}$ & 0.23 \\
$\mathrm{NaCl}$ & 0.23 \\
$\mathrm{MgSO}_{4} \cdot 7 \mathrm{H}_{2} \mathrm{O}$ & 0.17 \\
$\mathrm{CuSO}_{4} \cdot 5 \mathrm{H}_{2} \mathrm{O}$ & 0.15 \\
$\mathrm{MnSO}_{4} \cdot 4 \sim 5 \mathrm{H}_{2} \mathrm{O}$ & 0.13 \\
$\mathrm{ZnSO}_{4} \cdot 7 \mathrm{H}_{2} \mathrm{O}$ & 0 \\
$\mathrm{CoSO}_{4} \cdot 7 \mathrm{H}_{2} \mathrm{O}$ & 0 \\
$\mathrm{NiSO}_{4} \cdot 6 \mathrm{H}_{2} \mathrm{O}$ & 0 \\
$\mathrm{None}$ & 0.26 \\
\hline
\end{tabular}

Substrate: $\alpha$-Ketoglutarate $1 \mathrm{~mm}$ (final).

a Each concentration: $0.1 \mathrm{~mm}$ (final).

$b$ The protein concentration of the crude enzyme solution was $3.47 \mathrm{mg} / \mathrm{ml}$ reaction mixture.

extract, with incubation at $25^{\circ} \mathrm{C}$ for $10 \mathrm{~min} . \alpha-$ Ketoglutarate was the most effective compound among the compounds tested, which included L-glutamate, $\gamma$-amino- $n$-butyric acid, succinic semialdehyde, succinic acid, L-alanine, $\beta$-alanine, L-methionine, $S$-adenosyl methionine and 1-aminocyclopropane 1-carboxylic acid. The ethylene formation from succinic semialdehyde was about one-tenth that from $\alpha$-ketoglutarate (data not shown). It was noted that L-methionine and 1-aminocyclopropane 1-carboxylic acid, which are known as precursors of ethylene in higher plants, had no effect on this system.

Next, we used the crude enzyme preparation to examine the effects of metal ions on the ethylene formation. As is clear in Table I, the only effective metal on the ethylene formation from $\alpha$-ketoglutarate was ferrous sulfate. Among various ions, $\mathrm{Zn}^{2+}, \mathrm{Co}^{2+}$, and $\mathrm{Ni}^{2+}$ strongly inhibited the ethylene formation.

Based on the results, we tentatively constructed an ethylene-forming system containing the following: $1 \mathrm{~mm} \alpha$-ketoglutaric acid, $0.075 \mathrm{~mm}$ ferrous sulfate, $2 \mathrm{~mm}$ dithiothreitol, 


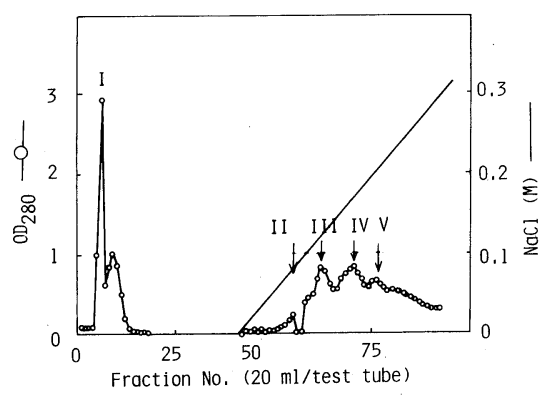

FIG. 1. DEAE-Sepharose CL-6B Ion Exchange Column Chromatogram of the Crude Enzyme Preparation.

TABle II. Reciprocal Relations Among Chromatographic Fractions

\begin{tabular}{cc}
\hline Fraction No. & $\begin{array}{c}\text { Ethylene production rate } \\
(\mathrm{nl} / \mathrm{ml} \text { reaction mixture/hr) }\end{array}$ \\
\hline I & 0 \\
II & 0.16 \\
III & 0.20 \\
IV & 0.20 \\
V & 0.26 \\
I + II + III + IV + V & 1.21 \\
I + II + III + IV & 1.38 \\
I + II + III + V & 0.27 \\
I + II + IV + V & 1.38 \\
I + III + IV + V & 1.39 \\
II + III + IV + V & 0.18 \\
I + IV & 1.30 \\
\hline
\end{tabular}

a The protein concentration of each fraction was: I (1.3), II (0.3), III (0.9), IV (0.9) and V (0.75) (mg/ml each fraction). The volume of each fraction added was $0.04 \mathrm{ml}$ and rest comprised $50 \mathrm{~mm}$ HEPES buffer ( $\mathrm{pH} 8.0$ ) in a total $0.2 \mathrm{ml}$. $\alpha$-Ketoglutarate, $\mathrm{FeSO}_{4} \cdot 7 \mathrm{H}_{2} \mathrm{O}$ and dithiothreitol were also added at $1 \mathrm{~mm}, 0.075 \mathrm{~mm}$ and $0.5 \mathrm{~mm}$ to the reaction mixture.

$20 \mathrm{~mm}$ HEPES buffer (pH 8.0) and the crude enzyme preparation; with incubation at $25^{\circ} \mathrm{C}$ for $10 \mathrm{~min}$ in a test tube (15-mm diameter, 13$\mathrm{ml}$ capacity) with a rubber stopper. However, it should be noted that the activity of ethylene formation of the system was less than $10 \%$ of that of living cells.

\section{DEAE-Sepharose chromatography}

In order to separate active fractions from the crude enzyme preparation, DEAESepharose CL-6B ion exchange chromatography was performed. Figure 1 shows a typical chromatogram. Fraction I, the void fraction
Table III. EfFects of Amino Acids AND Casamino Acid on Ethylene Formation

\begin{tabular}{lc}
\hline $\begin{array}{l}\text { Amino acid added } \\
\text { to fraction IV }\end{array}$ & $\begin{array}{c}\text { Ethylene prod. rate } \\
\text { (nl/ml reaction mix./hr) }\end{array}$ \\
\hline Casamino acid & 40.50 \\
L-Cysteine & 0.97 \\
L-Threonine & 1.15 \\
L-Serine & 0.70 \\
L-Hydroxyproline & 0.66 \\
L-Histidine & 1.81 \\
L-Tryptophan & 0.71 \\
L-Isoleucine & 0.79 \\
L-Proline & 0.89 \\
L-Glutamine & 0.90 \\
L-Asparagine & 0.71 \\
Glycine & 0.82 \\
L-Valine & 1.14 \\
L-Lysine & 0.76 \\
L-Aspartic acid & 0.89 \\
L-Arginine & 42.22 \\
L-Glutamic acid & 0.83 \\
L-Phenylalanine & 0.68 \\
L-Leucine & 0.88 \\
L-Methionine & 0.84 \\
L-Alanine & 0.66 \\
L-Tyrosine & 0.70 \\
None & 0.73 \\
\hline
\end{tabular}

The fraction IV concentration was $0.1 \mathrm{mg}$ protein $/ \mathrm{ml}$ reaction mixture. The casamino acid and amino acid concentrations were $2 \mathrm{mg} / \mathrm{ml}$ reaction mixture and $2 \mu \mathrm{mol} / \mathrm{ml}$ reaction mixture, respectively. $\alpha$-Ketoglutarate, $\mathrm{FeSO}_{4} \cdot 7 \mathrm{H}_{2} \mathrm{O}$ and dithiothreitol were added at the same concentrations as in Table II.

that passed through the column, and eluted fractions II to V hardly contained any ethylene-forming activity. We, therefore, tested combinations of the fractions. A mixture of fractions $\mathrm{I}$ to $\mathrm{V}$ showed strong ethylene formation activity and the coexistence of fractions I and IV was essential for the activity, as can be seen in Table II. This suggests that plural factors are needed for the ethylene formation.

To determine the essential factor in fraction I, the basal properties of the factor were examined. It was ninhydrin-positive, dialyzable and heat stable. With such properties, the active factor in fraction I may be an amino acid or peptide. Table III shows the effects of amino acids and casamino acid on the ethylene formation with fraction IV as the active en- 


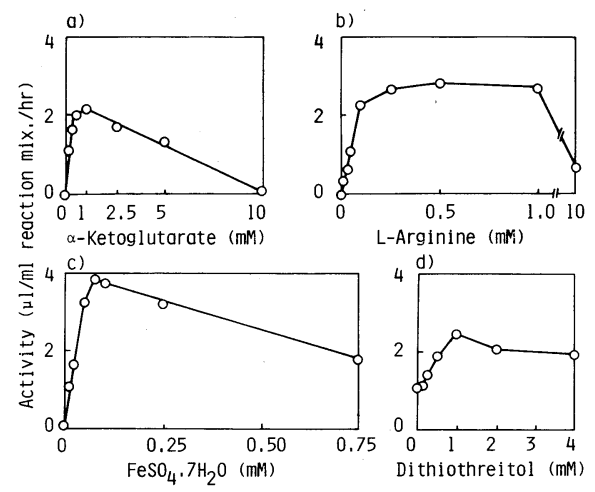

FIG. 2. Effect of the Concentrations of Essential Components in the Reaction System.

a) $\alpha$-ketoglutarate; b) L-arginine; c) $\mathrm{FeSO}_{4} \cdot 7 \mathrm{H}_{2} \mathrm{O}$; d) dithiothreitol.

When the concentration of one component was changed, the others were fixed as follows: $1 \mathrm{~mm} \alpha$-ketoglutarate, $0.5 \mathrm{~mm}$ L-arginine, $0.075 \mathrm{~mm} \mathrm{FeSO}_{4} \cdot 7 \mathrm{H}_{2} \mathrm{O}$ and $1 \mathrm{~mm}$ dithiothreitol, respectively. The protein concentration of the .ethylene-forming enzyme used was $0.33 \mathrm{mg} / \mathrm{ml}$ reaction mixture.

zyme. It was found that fraction I could be substantially replaced by casamino acid and especially by L-arginine. This is valuable information for comprehension of the detailed mechanism of ethylene formation.

\section{Construction of a cell-free ethylene-forming} system

The optimal concentrations of the essential compounds for ethylene formation by the cellfree system were determined. As shown in Fig. 2 , the optimal concentrations of $\alpha$-ketoglutarate, L-arginine, ferrous ions and dithiothreitol were $1 \mathrm{~mm}, 0.5 \mathrm{~mm}, 0.075 \mathrm{~mm}$ and 1 $\mathrm{mm}$, respectively. Inhibition of the reaction was observed at a higher concentration of each of these compounds. Finally, we succeeded in the construction of a cell-free ethylene-forming system using the partially purified enzyme from Penicillium digitatum IFO 9372. The reaction mixture contained the following: $1 \mathrm{~mm} \alpha$-ketoglutaric acid, $0.5 \mathrm{~mm}$ L-arginine, $0.075 \mathrm{~mm}$ ferrous sulfate, $1 \mathrm{~mm}$ dithiothreitol, $20 \mathrm{~mm}$ HEPES buffer ( $\mathrm{pH} 8.0$ ) and the partially purified enzyme fraction; with incubation at $25^{\circ} \mathrm{C}$ in a sealed test tube.

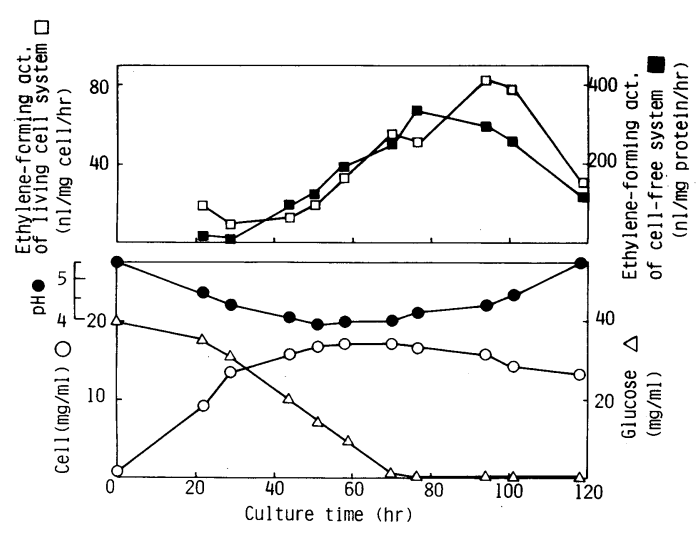

FIG. 3. Time Courses of Ethylene-forming Activities of Living Cell and Cell-free Systems.

$\bigcirc-O$, cell concentration; $\triangle-\triangle$, glucose concentration; - $-\mathrm{pH} ; \square-\square$, ethylene-forming activity of the living cell system; $\mathbf{\square}-\mathbf{\square}$, ethylene-forming activity of the cellfree system.

Comparison of the time course of ethyleneforming activity of the cell-free system with that of the living-cell system

Figure 3 is a comparison of the time course of ethylene-forming activity of the reaction system (cell-free system) with that of the livingcell system (in vivo) of the fungus. Clearly, the two time courses are similar (see the open and closed squares in Fig. 3). We believe that this cell-free ethylene-forming system really operates in living cells. And thus this reaction system is a very valuable tool for the elucidation of the ethylene forming mechanism in this fungus.

\section{Substrate specificity for ethylene formation}

The origin of ethylene was first confirmed because of the necessity of two carbon compounds, $\alpha$-ketoglutarate and $\mathrm{L}$-arginine, in the reaction mixture. The $\left[\mathrm{U}-{ }^{14} \mathrm{C}\right]$ forms of the two compounds were used for the reaction. The ethylene generated was trapped with $0.1 \mathrm{M}$ mercuric acetate in methanol, ${ }^{10}$ and radioactivity was determined with a scintillation counter, RackBeta 1217, LKB, Wallac. It was found that ${ }^{14} \mathrm{C}$-ethylene was formed only from $\left[\mathrm{U}-{ }^{14} \mathrm{C}\right] \alpha$-ketoglutarate and not from $\mathrm{L}-\left[\mathrm{U}-{ }^{14} \mathrm{C}\right]$ arginine (data not shown).

The substrate specificity for the cell-free 
Table IV. Substrate Specificity for ETHYLENE FORMATION

\begin{tabular}{lc}
\hline \multicolumn{1}{c}{ Substrate ${ }^{a}$} & $\begin{array}{c}\text { Ethylene formation rate } \\
\text { (nl/ml reaction mix. } / \mathrm{hr})\end{array}$ \\
\hline L-Methionine & 0 \\
S-Adenosylmethionine (SAM) & 0 \\
1-Aminocyclopropane-1- & 0 \\
$\quad$ carboxylic acid (ACC) & \\
$\alpha$-Keto- $\gamma$-methiolbutyric acid & 23.1 \\
$\quad$ KMB) & 0.9 \\
L-Glutamic acid & 760.2 \\
$\alpha$-Ketoglutaric acid & 1.0 \\
$\gamma$-Aminobutyric acid & 2.0 \\
Succinate semialdehyde & 0 \\
$\alpha$-Ketobutyric acid & 0.7 \\
DL- $\alpha$-Keto- $\beta$-methyl- $n-$ & \\
$\quad$ valeric acid & 0 \\
$\alpha-$ Ketoisocaproic acid & 0 \\
$\alpha-$ Ketoadipic acid & 0 \\
None &
\end{tabular}

a Each concentration: $1 \mathrm{~mm}$ (final concentration)

$b$ The protein concentration of the ethylene-forming enzyme (=fraction IV) was $0.17 \mathrm{mg} / \mathrm{ml}$ reaction mixture. The reaction mixture contained $0.1 \mathrm{ml}$ substrate, $0.1 \mathrm{ml} 5 \mathrm{mM}$ L-arginine, $0.1 \mathrm{ml} \quad 0.75 \mathrm{~mm}$ $\mathrm{FeSO}_{4} \cdot 7 \mathrm{H}_{2} \mathrm{O}, 0.1 \mathrm{ml} 10 \mathrm{~mm}$ dithiothreitol, $0.4 \mathrm{ml}$ $50 \mathrm{~mm}$ HEPES buffer ( $\mathrm{pH} 8.0$ ), $0.1 \mathrm{ml} \mathrm{H}_{2} \mathrm{O}$ and $0.1 \mathrm{ml}$ ethylene-forming enzyme.

ethylene formation was next examined. As shown in Table IV, the rate of formation of ethylene from $\alpha$-keto- $\gamma$-methiol butyric acid (Sigma Chemical Co., Ltd., U.S.A.) was very low, being only about $3 \%$ of that from $\alpha$ ketoglutaric acid.

Since homogenates or cell-free systems of higher plants and microorganisms were previously found to be inactive as to ethylene formation, progress in the elucidation of ethylene biosynthesis was due to studies with model systems. ${ }^{1)}$ These model systems convert linolenic acid, ${ }^{11,12)}$ methionine, ${ }^{13)}$ methional or $\alpha$-keto- $\gamma$-methylthiobutyrate, ${ }^{14)}$ or propanal $^{15)}$ to ethylene in the presence of metal catalysts or free radical generating systems. Lieberman $^{1)}$. suggested the participation of some kind of peroxidase reaction in in vivo ethylene formation. According to the above information, the partially purified enzyme preparation (fraction IV in Fig. 1) might be possibly used to detect an arginine oxidase activity or a peroxidase activity. Studies are now in progress on further purification of the enzyme and on the biochemical mechanism of the ethylene formation by Penicillium digitatum IFO 9372.

Acknowledgments. The authors are deeply indebted to Dr. S. Akiyama, Takeda Chemical Industries, Ltd. (Osaka, Japan), for the helpful discussions and suggestions. The experimental help and discussion of Miss M. Kosai of this department are also much appreciated.

\section{REFERENCES}

1) M. Lieberman, Ann. Rev. Plant Physiol., 30, 533 (1979)

2) D. O. Adams and S. F. Yang, Proc. Natl. Acad. Sci. U.S.A., 76, 170 (1979).

3) D. L. Ketring, R. E. Young and J. B. Biale, Plant Cell Physiol., 9, 617 (1968).

4) D. W. Jacobsen and C. H. Wang, Plant Physiol., 43, 1959 (1968).

5) C. H. Wang, A. Persyn and J. Krackov, Nature, 195, 1306 (1962).

6) D. W. Jacobsen and C. H. Wang, Plant Physiol., (suppl.), 40, 19 (1965).

7) M. S. Gibson and R. E. Young, Nature, 210, 529 (1966).

8) T. W. Chou and S. F. Yang, Arch. Biochem. Biophys., 157, 73 (1973).

9) H. Fukuda, T. Fujii and T. Ogawa, Agric. Biol. Chem., 48, 1363 (1984).

10) M. S. Gibson and F. L. Crane, Plant Physiol., 38, 729 (1963).

11) M. Lieberman and L. W. Mapson, Nature, 195, 1016 (1962).

12) M. Lieberman and L. W. Mapson, Nature, 204, 343 (1964).

13) M. Lieberman, A. T. Kunishi, L. W. Mapson and L. W. Wardale, Biochem. J., 97, 449 (1965).

14) S. F. Yang, H. S. Ku and H. K. S. Pratt, J. Biol. Chem., 242, 5274 (1966).

15) M. Lieberman and A. T. Kunishi, Science, 158, 938 (1967). 